(RESEARCH ARTICLE)

\title{
Biodegradable chitosan coating for improving quality and controlling Alternaria alternata growth in figs
}

\author{
Sergio Contreras Saavedra 1, Rosa Isela Ventura-Aguilar ${ }^{2}$, Silvia Bautista-Baños ${ }^{1}$ and Laura Leticia Barrera- \\ Necha ${ }^{1, *}$ \\ ${ }^{1}$ Centro de Desarrollo de Productos Bióticos, Instituto Politécnico Nacional, Carretera Yautepec-Jojutla km 6, 62731, \\ Yautepec, Morelos, México. \\ ${ }^{2}$ CONACYT-CEPROBI, Instituto Politécnico Nacional, Carretera Yautepec-Jojutla km 6, 62731, Yautepec, Morelos, México.
}

Publication history: Received on 05 July 2020; revised on 13 August 2020; accepted on 15 August 2020

Article DOI: https://doi.org/10.30574/wjarr.2020.7.2.0246

\begin{abstract}
The objective of this work was to evaluate the effect of a chitosan biodegradable coating (BC), functionalized with cinnamon essential oil and aqueous extract of Roselle calyces, on the quality, respiratory rate, anthocyanin content and antioxidant capacity using the ABTS radical. Figs 'Black Mission' of two maturity stages were used. The first maturity stage included purple fruits (14\% SST), referred to as "ripe figs". The second stage was unripe figs, which presented a green color in $25 \%$ of its surface (11\% SST). Five treatments were applied for each fig maturity stage. $150 \mathrm{~g}$ of figs was kept into clamshells packaging at $5{ }^{\circ} \mathrm{C}$ for $0,4,10,15$ and 21 days, before being transferred to room temperature $(20$ ${ }^{\circ} \mathrm{C}$ ) for 2 more days. The BC structure was evaluated with the use of SEM. Furthermore, quality of this fruits as a result of the use $\mathrm{BC}$ and the different storage conditions was determined. The incidence and severity of rotting caused by $A$. alternata was quantified. The matrix of the $\mathrm{BC}$ was porous and heterogeneous. The unripe figs treated with $\mathrm{BC}$ and preventive treatments showed a lower weight loss, color change, respiration rate, and anthocyanin content than the control group. Meanwhile, the ripe figs receiving the preventive, curative and coated treatments, only showed the smallest color changes compared to the remaining treatments, but the remaining variables were similar to those of the control group. Finally, A. alternata did not grow at $5{ }^{\circ} \mathrm{C}$ in unripe figs but only in the ripe ones. The $\mathrm{BC}$ preserved the physicochemical and microbiological quality of unripe figs at $5^{\circ} \mathrm{C}$ for 21 days.
\end{abstract}

Keywords: Ficus carica; Storage; Shelf-life; Fungi; Postharvest

\section{Introduction}

The fig tree (Ficus carica L.) is of Mediterranean origin and 1143 thousand tons per year are produced worldwide. The main producers of this fruit are Turkey, Egypt, and Morocco with 54\% of world production and Mexico rank 19th (FAOSTAT, 2018). The demand for this fruit is for fresh consumption, although it can also be sold as a dehydrated or processed product. It is an excellent source of minerals, vitamins, dietary fiber, amino acids and antioxidants (Veberic et al., 2008; Self Nutrition Data, 2018). Due to its nutritional composition, its fresh marketing is affected by the growth of fungi such as Alternaria alternate (Fr. Keissler). This is the causative agent of the disease known as black mold, which is the one with the highest incidence, and the one that causes losses of up to nearly $30 \%$ of the product postharvest (Doster \& Michailides, 2007). These losses could be the result of phytosanitary restrictions established by importing countries, which limit the use of synthetic fungicide products.

In addition, there is very little information on fungicides of natural origin that could be used not only as part of an integrated disease management process during production and leading up to the commercialization of the fig. Hence, the development and application of chitosan-based BC in postharvest represent a reliable alternative. This is because these form a semipermeable barrier that reduces water loss and controls gas exchange $\left(\mathrm{O}_{2}\right.$ and $\left.\mathrm{CO}_{2}\right)$, the emission of

\footnotetext{
* Corresponding author: Laura Leticia Barrera-Necha; phone 52735138 6061; e-mail: Ibarrera@ipn.mx
} 
ethylene, and reduces the risk of microbiological contamination in the products that contain them. Additionally, BC can be functionalized with essential oils and plant extracts that, in addition to conferring a greater antimicrobial composition, provide bioactive compounds of interest to the health of consumers (Bautista-Baños et al., 2017).

To date, edible chitosan coatings have been formulated and applied to preserve the sensory and microbiological quality of the fig. For instance, Reyes-Avalos et al. (2016) undertook that the application of alginate-chitosan bilayer edible film on figs 'Black Mission' contributed to retaining the color and retarded the visual fungi contamination during 12 days of storage at $6{ }^{\circ} \mathrm{C}$. Lakshmi et al. (2018) studied the effect of chitosan edible coating conjunction with Zinc oxide nanoparticles synthesized from spinach (Spinacia oleracea) leaves with Zinc nitrate hexahydrate solution as a precursor, on the quality parameters of figs (Ficus carica L.). They reported that when using edible coating together with $\mathrm{ZnO}$ nanoparticles at $175 \mathrm{ppm}$, the fig fruit delayed ripening, had less weight loss, had a reduced in the color changes, were firmer, and the growth of microorganisms compared to uncoated figs was inhibited. This suggests that the use of a blend of antimicrobial and bioactive compounds could enhance their effect. In this sense, the objective of this work was to evaluate the effect of a chitosan BC, functionalized with cinnamon oil and aqueous extract of Roselle calyces, on the quality, respiratory rate, anthocyanin content and antioxidant capacity using the ABTS radical.

\section{Material and methods}

\subsection{Formulation of $B C$}

Aqueous chitosan solution at $0.4 \%$ (MW of $89305.6 \pm 1850 \mathrm{~g} \mathrm{~mol}^{-1} ; 10.6 \pm 0.3$ degrees of acetylation) was prepared with $0.5 \%$ acetic acid. It was blended by stirred at $55^{\circ} \mathrm{C}$ for $1.5 \mathrm{~h}$ with the $\mathrm{pH}$ being adjusted to 5.2 using $1 \mathrm{~N} \mathrm{NaOH}$. On the other way, prior to use, Roselle calyces commercially acquired were washed with distilled water to remove excess dust. An aqueous extract was then prepared at a concentration of $15 \%$. The blending was maintained for $24 \mathrm{~h}$ at room temperature and in darkness. The aqueous phase was recovered by filtration for subsequent use.

A BC solution was produced using the method suggested by Ventura-Aguilar et al. (2018). Blending of edible canola oil at $1 \%$ (Valley Foods, Mexico) and cinnamon essential oil at $0.025 \%$ (Oils and essences, Mexico) was added to the $0.4 \%$ aqueous chitosan solution. Final blending was homogenized for $10 \mathrm{~min}$ at $14000 \mathrm{rpm}$ (Virtis Gardiner model 45, USA). Subsequently, $1 \%$ of aqueous extract of Roselle calyces and $0.1 \%$ of tween 20 (Hycel, Mexico) were added. The solution was homogenized at $14000 \mathrm{rpm}$ for 10 minutes again.

\subsection{Culture and spores suspension of Alternaria alternata}

The A. alternata strain was isolate of figs from an orchard located in Telixtac Axochiapán, Morelos, México $\left(18^{\circ} 34^{\prime} 12.75\right.$ "N and $98^{\circ} 46^{\prime} 11.04^{\prime \prime} \mathrm{W}$ ) and provided by the Agricultural Products Postharvest Technology Laboratory of CEPROBI, Mexico. The strains were cultured at $28^{\circ} \mathrm{C}$ on a PDA medium. After 7 days of growth, the spores were harvested. $20 \mathrm{~mL}$ of sterile water was then added to the surface of the Petri dish and was then scraped with a sterile glass rod. The resulting solution was filtered through sterile cheesecloth to eliminate the mycelia present. After filtration, $50 \mu \mathrm{L}$ of the solution was taken and placed in a hematocytometer. The final concentration of spores was adjusted at $1 \times 10^{5}$ spores $\mathrm{mL}^{-1}$ using an optical Nikon Eclipse E600 microscope.

\subsection{Plant material characteristic}

'Black Mission' figs with two maturity stage were harvested from a commercial orchard in Morelos, Mexico $\left(18^{\circ} 49^{\prime}\right.$ $19^{\circ} 01^{\prime}$ north latitude and $98^{\circ} 37^{\prime}-98^{\circ} 47^{\prime}$ west longitude). The first maturity stage included purple fruits ( $14 \%$ of total soluble solids, TSS), referred to as "ripe figs" in this work. The second stage was unripe figs, which presented a green color in $25 \%$ of their surface $(11 \%$ TSS).

\subsection{Experimental conditions and treatments}

The figs were selected to eliminate those with defects and were disinfected using an aqueous solution of sodium hypochlorite at $200 \mathrm{ppm}$. Random samples were selected and 10 batches were established with 21 experimental units for each. The experimental unit was made up of $150 \mathrm{~g}$ of figs that were placed inside clamshell containers. In the fruits that were inoculated with the fungus, two wounds were made in their equatorial region, after which $10 \mu \mathrm{L}$ of spore suspension $\left(1 \times 10^{5}\right.$ spores $\left.\mathrm{mL}^{-1}\right)$ was deposited. In the case of fruits treated with $\mathrm{BC}, 0.5 \mathrm{~mL}$ of $\mathrm{BC}$ was sprinkled covering the whole fig. Five treatments were applied for each maturity stage as follows: T1. The control group (no fungi and no cover), T2. Figs coated with BC (coated), T3. Figs with BC and after 3 hours inoculated with A. alternata (preventive), T4. Figs inoculated with $A$. alternata and after 3 hours coated with BC (curative) and T5. Figs inoculated with $A$. 
alternata. The figs $(150 \mathrm{~g})$ were kept into clamshells packaging at $5{ }^{\circ} \mathrm{C}$ during days $0,4,10,15$ and 21 , and after transferring to room temperature $\left(20^{\circ} \mathrm{C}\right)$ for 2 more days.

\subsection{Characterization of the coating by scanning electron microscopy (SEM)}

A film elaborated with chitosan, cinnamon essential oil and Roselle calyces of $23 \mu \mathrm{m}$ thick was fractured by immersion in liquid nitrogen. It was then coated with carbon to create a conductive surface. The samples were analysed using a JSM 7800F Ultra High-Resolution Scanning Microscope (JOEL, USA).

\subsection{Quality evaluation}

Weight loss was calculated as the difference between initial fresh weight and weight on each day of evaluation. The result was expressed as a percentage of weight loss. Firmness was reported in Newton $(\mathrm{N})$ and measured in the equatorial region of the fruit using a digital penetrometer (Turoni, Italy), equipped with a cylindrical tip of $3 \mathrm{~mm}$ diameter. Titratable acidity (TA) was determined on $20 \mathrm{~g}$ of fruit, which was macerated with $100 \mathrm{~mL}$ of distilled water. Blending was filtered and after $5 \mathrm{~mL}$ aliquot was recovered, it was titrated with $0.1 \mathrm{~N} \mathrm{NaOH}$ until a pH of 8.3 was achieved. TA was reported as a percentage considering the value of citric acid as the majority of organic acid (AOAC, 2005). To quantify the total soluble solids (TSS), $0.3 \mathrm{~mL}$ of fruit juice was analysed using a refractometer (Atago N-1E, Japan) and the results were reported as a percentage.

To measure color a Konika Minolta Colorimeter (Sensing, Japan) was used, obtaining values for L* (luminosity), a * (red-green) and $\mathrm{b}^{*}$ (blue-yellow). The results were reported as a color change $(\Delta \mathrm{E})$ with regard to the fruit on each evaluation day with respect to the initial day, according to the following equation.

$$
\Delta E=\sqrt{\left(L_{\text {day } 0}-L_{\text {final day }}\right)^{2}+\left(a_{\text {day } 0}-a_{\text {final day }}\right)^{2}+\left(b_{\text {day } 0}-b_{\text {final day }}\right)^{2}}
$$

\subsection{Respiration rate}

Respiration rate was measured using the $\mathrm{CO}_{2}$ content released by the fruit. The figs were then stored in hermetically sealed $1 \mathrm{~L}$ glass jars for $2 \mathrm{~h}$. Subsequently, $1 \mathrm{~mL}$ of the gas was taken and analysed using a 7890B CG gas chromatograph (Agilent Technologies, U.S.A). The equipment was adapted with two detectors (FID / TCD) and two HP-PLOT / Q and CPMOLSIEVE 5A columns (Agilent Technologies, U.S.A). Injector and detector temperatures (FID and TCD) were 220, 300 and $250^{\circ} \mathrm{C}$, respectively. The injector remained in Split 1:10 mode. Helium was used as a carrier gas at a flow rate of $1 \mathrm{~mL} \mathrm{~min}{ }^{-1}$. The respiration rate was expressed in $\mathrm{mL} \mathrm{CO}_{2} \mathrm{Kg}^{-1} \mathrm{~h}^{-1}$ as was reported by Baldoni et al. (2016).

\subsection{Anthocyanins and antioxidant capacity}

Anthocyanins content was determined by the method proposed by Aguilera-Ortiz, et al. (2009) and Kou et al. (2019). This consisted of macerating $20 \mathrm{mg}$ of fig peel with $6 \mathrm{~mL}$ of a solution composed of 35\% hydrochloric acid, distilled water, and methanol (HCl: $\mathrm{H} 2 \mathrm{O}: \mathrm{MeOH} / 1: 49: 50)$. Blending was centrifuged at $3448 \mathrm{~g}$ for $10 \mathrm{~min}$ (Eppendorf centrifuge, USA). Subsequently, the supernatant was recovered and its absorbance measured at $520 \mathrm{~nm}$ using a spectrometer (Genesys 10S UV-VIS, USA). The anthocyanin content was reported as cyanidin 3-glycoside expressed in $\mathrm{mg} \mathrm{kg}^{-1}$, using a molar absorption coefficient $(\varepsilon)$ of $26900 \mathrm{~L} \mathrm{~cm}^{-1} \mathrm{mg}^{-1}$ and a molecular weight of $449.2 \mathrm{~g} \mathrm{~L}^{-1}$.

Antioxidant capacity was evaluated using ABTS $^{+}$assay according to the method proposed by Re et al. (1999) and Kuskoski et al. (2005). ABTS ${ }^{+}$radical cations were produced by reacting 7 mM ABTS stock (2,2'-Azino-bis(3ethylbenzothiazoline-6-sulfonic acid) diammonium salt) solution with $2.45 \mathrm{mM}$ potassium persulfate and allowing the mixture to stand in the dark at room temperature for $12-16 \mathrm{~h}$ before use. The ABTS+ solution was diluted with methanol to an absorbance of $0.70 \pm 0.02$ at $754 \mathrm{~nm}$. The degree of quenching of radical generation in individual samples, indicative of the presence of antioxidant activity, was quantified by comparison with a standard curve of 0 a $22 \mu \mathrm{M}$ Trolox (6-Hydroxy-2,5,7,8-tetramethylchromane-2-carboxylic acid) and expressed as Trolox equivalent antioxidant capacity or TEAC.

\subsection{Incidence and severity of $A$. alternata on figs}

Incidence was calculated by quantifying the infected figs with respect to the total number of figs that made up the experimental unit. The severity of the disease was determined by assessing the percentage of damage with regard to each fruit. The results of days 21 to 24 are reported as the period of time in which fungal growth was observed. 


\subsection{Statistical analysis}

Assays were performed in triplicate for each sample and data were analysed using an ANOVA with a factorial arrangement. Results were expressed as mean values \pm standard deviation (SD) and compared by Tukey test $(\mathrm{p} \leq 0.05)$ using Sigma Plot 12.5 software (Systat Software Inc., 2011).

\section{Results and discussion}

\subsection{Structural characterization of BC by SEM}

A Cross-section of BC showed a rough, uniform structure and without fractures (Figure 1A and 1B), while on the surface, a heterogeneous, porous and rough matrix was observed (Figure 1C and 1D). Notably, the presence of pores favors gas exchange in the fruit. As expected, this could be because of the two phases (oily and aqueous) that compound the emulsion of BC. Hosseini et al. (2009) indicated that when adding essential oils to a chitosan matrix, the union of their chains is interrupted, due to the hydrophobicity of the essential oils, which causes greater porosity. Similarly, Martínez et al. (2018) observed that by adding thyme essential oil (Thymus capitatus) to a blending of $2 \%$ chitosan, glycerol and tween 80, a more heterogeneous and sponge-like texture is obtained, but one which still maintains its functionality.
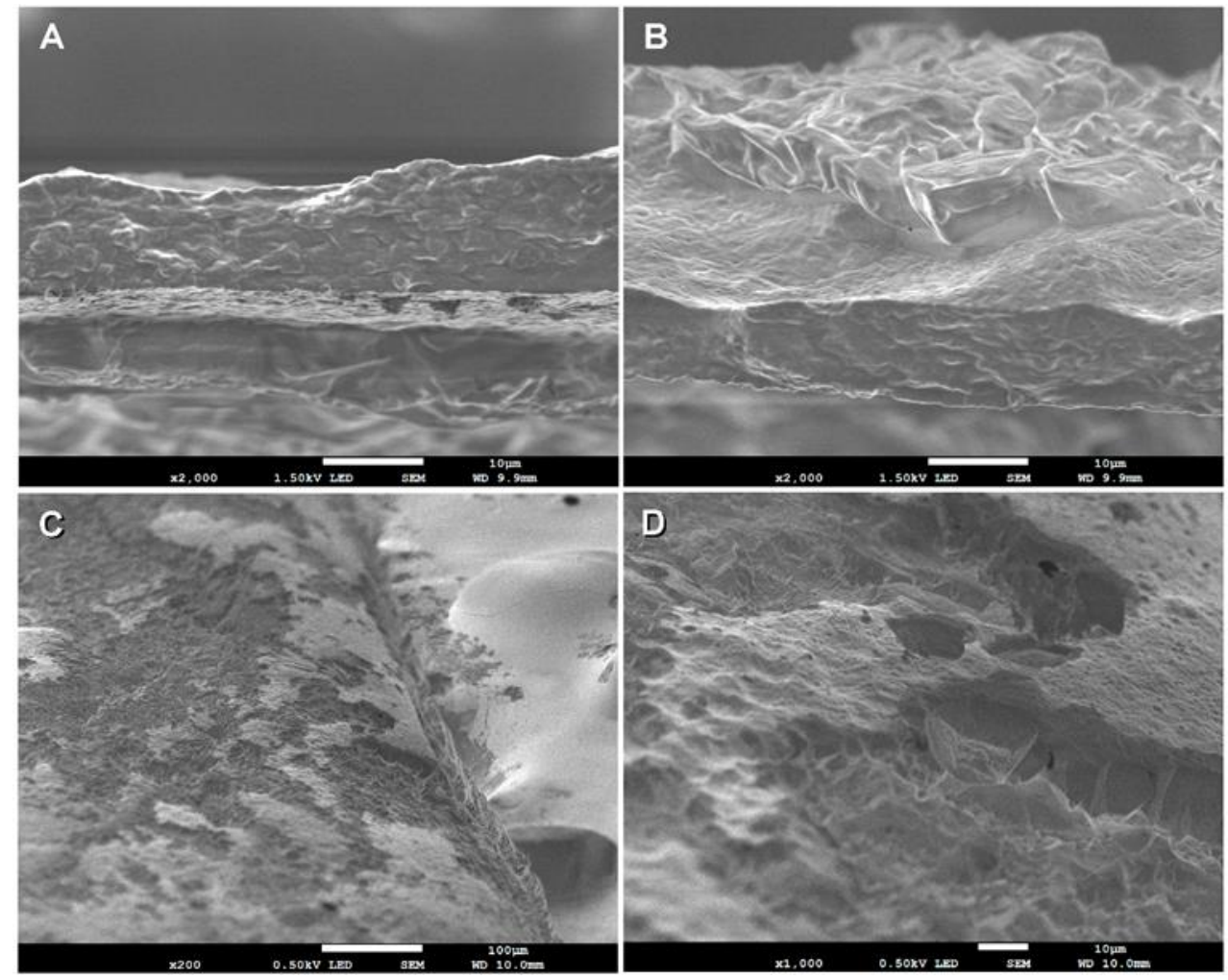

Figure 1 Micrographs of BC. A) Cross-section, B) cross and side section, C) side section and D) side section

\subsection{Effect of $B C$ on the quality of figs}

All fruits gradually lost weight $(p<0.001)$ throughout storage at $5{ }^{\circ} \mathrm{C}$ and $20^{\circ} \mathrm{C}$. This is probably, due to the natural process of transpiration, which causes water loss and therefore weight loss (Vazquez-Briones \& Guerrero-Beltrán, 2013). In addition, differences $(p<0.001)$ were observed in terms of their maturity stage. Only unripe figs showed significant differences $(p<0.001)$ in terms of the treatments applied. For example, figs inoculated with A. alternata and figs with curative treatment lost $11 \%$ more weight than the figs of the other treatments. At the same time, unripe fruits lost up to $10 \%$ of their weight at day 22, regardless of the treatment applied (Figure 2A and 2B). In this regard, Cantín et al. (2011) reported that $A$. alternata growth on unripe figs causes tissue damage, and consequently an increase in water loss, contrary to what is observed when the $\mathrm{BC}$ is placed on the fruit as a preventive treatment. The application of $\mathrm{BC}$ avoided deterioration because it forms a barrier on the fruit as was mentioned by Shan et al. (2007). Villalobos et al. (2016) reported a $7 \%$ weight loss in fig treated with a soy-based coating after 21 days of storage at $0{ }^{\circ} \mathrm{C}$, which is very similar to the values found in the present work. 


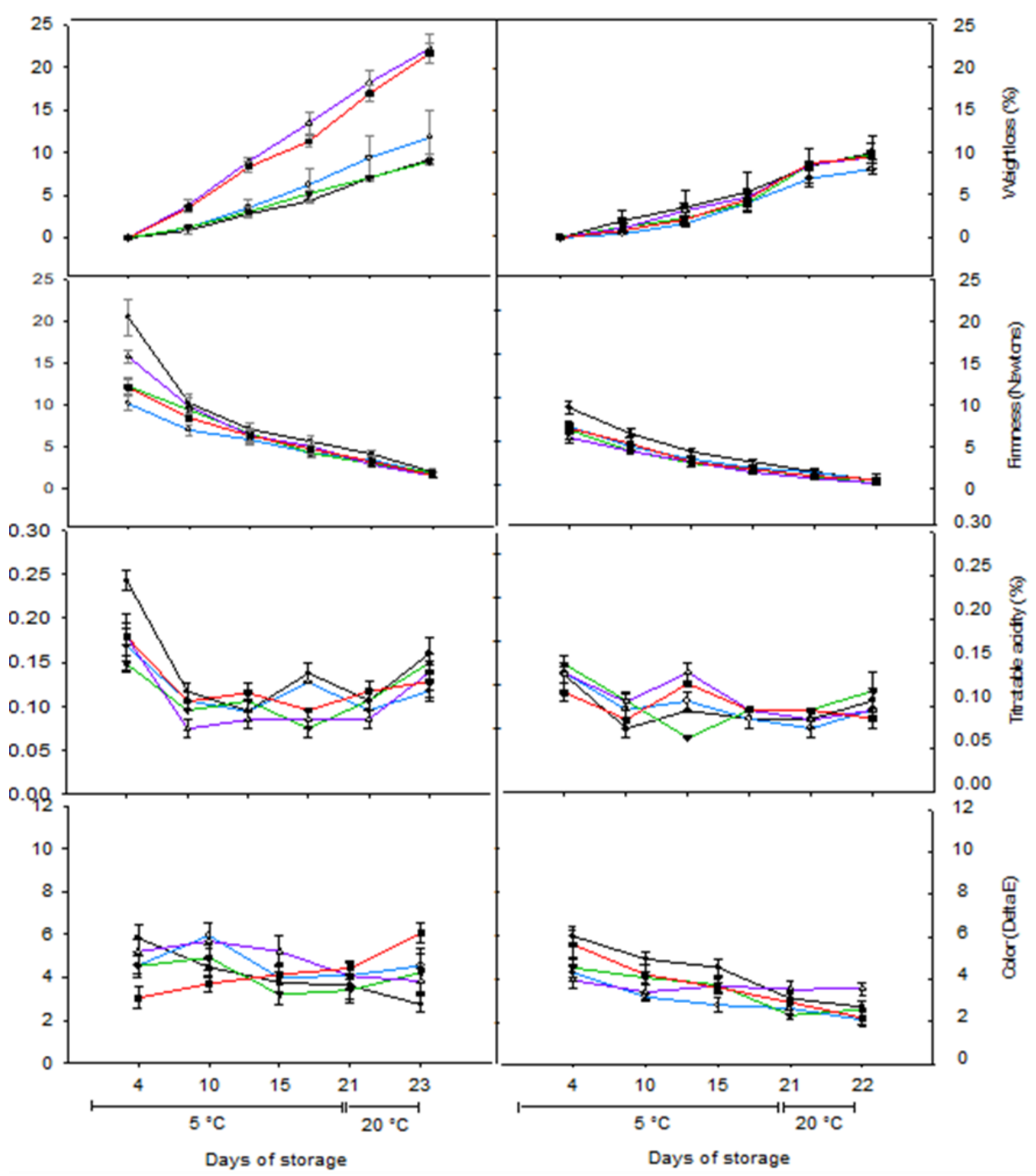

Figure 2 Quality variables of figs stored at $5{ }^{\circ} \mathrm{C}$ for $21 \mathrm{~d}$ and after at $20^{\circ} \mathrm{C}$. (A, C, E and G) unripe figs and (B, D, F and

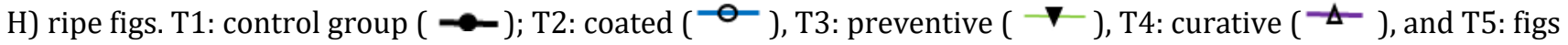
inoculated with A. alternata $(\rightarrow-)$. Vertical bars represent the standard deviation $(\mathrm{p} \leq 0.05)$.

There was a gradual reduction in the firmness of the figs over time, regardless of the treatment applied or its maturity stage, which can be explained as a result of the weight loss of the product as outlined previously. In this sense, neither the $\mathrm{BC}$ nor the growth of A. alternata negatively influenced this quality parameter (Figure 2C and 2D). Similarly, Allegra et al. (2017) reported a 50\% reduction in the firmness of the fig treated with an Opuntia ficus indica-based BC and stored at $4 \stackrel{\circ}{\circ}$ for 14 days.

In addition to firmness, it was observed that in the ripe figs, TA was up to $50 \%$ less than unripe ones during the first 4 days of storage at $5{ }^{\circ} \mathrm{C}$. After this time, the TA slightly diminished in both figs groups evaluated (ripe and unripe) without observing significant differences ( $\mathrm{p}<0.001$ ) in terms of the treatments applied (Figure $2 \mathrm{E}$ and $2 \mathrm{~F}$ ). This occurs because 
starch becomes sugars during the ripening process and consequently the acidity of the fruit diminishes (Marpudi et al., 2013). Furthermore, figs are considered climacteric, since ethylene induces postharvest ripening. Haci \& Özcan (2018) quantified a TA of $0.19 \%$ in figs stored for 14 days at $4{ }^{\circ} \mathrm{C}$ and treated with different packages and doses of ozone.

$\Delta \mathrm{E}$ of the figs was more evident in the ripe fruits of the control group and those inoculated with A. alternata. This can be explained because the control fruits did not have the same additional protection as fruits covered by BC. As a result, it has a more accelerated maturation and deterioration. Consequently, a major color change is observed. Similarly, the presence of $A$. alternata induces fruit rot and accelerated ripening (Latinović et al., 2014). By contrast, unripe figs did not show differences $(p<0.001)$ with regard to the treatments applied (Figure $2 \mathrm{G}$ and $2 \mathrm{H}$ ). This is because the fruits harvested before commercial maturity do not undergo considerable color changes as reported by Flaishman et al., (2007). Results similar to this study were reported by Reyes-Avalos et al. (2016) who quantified a $\Delta \mathrm{E}$ of 1.33 units in figs coated with an alginate/chitosan film and stored at $6^{\circ} \mathrm{C}$ for 15 days.

Table 1 Total soluble solids content in fig of two maturity stage

\begin{tabular}{|c|c|c|c|c|c|c|}
\hline & \multicolumn{6}{|l|}{ Days of storage } \\
\hline & $\mathbf{0}$ & 4 & 10 & 21 & 22 & 23 \\
\hline \multicolumn{7}{|c|}{ Unripe } \\
\hline $\mathrm{T} 1$ & $09.9 \pm 0.6 \mathrm{ABa}^{*}$ & $11.3 \pm 0.3 \mathrm{BCa}$ & $12.2 \pm 0.7 \mathrm{Ca}$ & $8.9 \pm 0.9 \mathrm{Aa}$ & --- & $9.9 \pm 0.7 \mathrm{ABab}$ \\
\hline $\mathrm{T} 2$ & $10.8 \pm 1.4 \mathrm{Aab}$ & $12.3 \pm 1.1 \mathrm{Aba}$ & $13.7 \pm 0.4 \mathrm{Ba}$ & $10.9 \pm 0.4 \mathrm{Aa}$ & --- & $12 \pm 0.8 \mathrm{ABb}$ \\
\hline $\mathrm{T} 3$ & $12.9 \pm 1.0 \mathrm{Ab}$ & $12.3 \pm 1.2 \mathrm{Aa}$ & $11.1 \pm 2 \mathrm{Aa}$ & $12.7 \pm 0.2 \mathrm{Aa}$ & --- & $10.3 \pm 0.5 \mathrm{Aab}$ \\
\hline $\mathrm{T} 4$ & $10.7 \pm 0.5 \mathrm{Aab}$ & $11.6 \pm 1.2 \mathrm{Aa}$ & $10.3 \pm 1.4 \mathrm{Aa}$ & $11.8 \pm 3 \mathrm{Aa}$ & --- & $9.8 \pm 0.5 \mathrm{Aa}$ \\
\hline T5 & $12.3 \pm 0.8 \mathrm{Aab}$ & $12.1 \pm 1.2 \mathrm{Aa}$ & $11.1 \pm 1.1 \mathrm{Aa}$ & $11.6 \pm 1.3 \mathrm{Aa}$ & --- & $11 \pm 1.2 \mathrm{Aab}$ \\
\hline \multicolumn{7}{|c|}{ Ripe } \\
\hline $\mathrm{T} 1$ & $13.1 \pm 0.3 \mathrm{Aa}$ & $13.3 \pm 1.3 \mathrm{Aab}$ & $12.2 \pm 0.2 \mathrm{Aa}$ & $14.1 \pm 0.7 \mathrm{Aa}$ & $13.6 \pm 0.72 \mathrm{Abc}$ & --- \\
\hline $\mathrm{T} 2$ & $15.1 \pm 1.0 \mathrm{Ba}$ & $13.1 \pm 1.3 \mathrm{Aba}$ & $12.7 \pm 0.5 \mathrm{ABa}$ & $13.1 \pm 1.6 \mathrm{ABa}$ & $11.4 \pm 1.20 \mathrm{Aab}$ & --- \\
\hline $\mathrm{T} 3$ & $13.6 \pm 1 \mathrm{ABa}$ & $14.5 \pm 0.8 \mathrm{Bab}$ & $16.5 \pm 0.6 \mathrm{Bb}$ & $14.3 \pm 1.2 \mathrm{Ba}$ & $10.8 \pm 0.69 \mathrm{Aa}$ & --- \\
\hline $\mathrm{T} 4$ & $13.3 \pm 1.6 \mathrm{Aa}$ & 15.1 $\pm 1.1 \mathrm{Aab}$ & $16 \pm 0.2 \mathrm{Ab}$ & $14.3 \pm 1.7 \mathrm{Aa}$ & $14.1 \pm 1 \mathrm{Ac}$ & --- \\
\hline T5 & $14.3 \pm 0.5 \mathrm{ABa}$ & $16.2 \pm 0.9 \mathrm{Bb}$ & $17.1 \pm 1.4 \mathrm{Bb}$ & $10.9 \pm 2.3 \mathrm{Aa}$ & $11.1 \pm 1.2 \mathrm{Aab}$ & --- \\
\hline
\end{tabular}

(--) Data not available since the trial stopped when the fruit was not suitable for commercialization. T1. Control group, T2. Figs coated with BC, T3. Figs of preventive treatment, T4. Figs of curative treatment and T5. Figs inoculated with A. alternata.

* Columns and rows with means with the same letter are not significantly different $(\mathrm{p}>0.05)$ by the Tukey test

Ripe figs had an average of $2.4 \%$ more TSS than unripe ones, due to higher concentrations of sucrose, glucose, fructose, and other oligosaccharides compared with unripe figs, regardless of the treatment used (Crisosto et al., 2010). For each maturity stage, figs showed different TSS content. For instance, unripe fruits coated with BC, and ripe figs gave a curative treatment, presented the highest values (12\% and $14.4 \%$, respectively) on days 10 and 15 . In both cases, the coating led to an increase in TSS. This was probably because this causes slight stress on the commodity that accelerates the ripening process and increases TSS (Table 1). Alturki (2013) evaluated the effect of packaging with different gas composition inside figs stored at $4{ }^{\circ} \mathrm{C}$ for 42 days, reporting a TSS content close to $16 \%$, which is not different from that obtained in this research. Finally, there were no significant changes in TSS content $(p<0.001)$ in terms of storage temperature. This could be because once the figs are harvested; they release ethylene (Kader, 2003). Then, the ripening process is very slow and the TSS does not increase considerably. Therefore the differences observed over time, could be attributed only to the variability of the sampled fruits.

\subsection{Effect of $B C$ on respiration rate}

Both ripe and unripe figs had a similar respiration rate $\left(100 \mathrm{~mL} \mathrm{CO}_{2} \mathrm{~kg}^{-1} \mathrm{~h}^{-1}\right)$, except to unripe figs inoculated with $A$. alternata and unripe figs given a curative treatment that showed the highest respiration c.a. $280 \mathrm{~mL} \mathrm{CO}_{2} \mathrm{~kg}^{-1} \mathrm{~h}^{-1} \mathrm{during}$ all storage period (Figure 3A and 3B). Evidencing that fungi growth increased the respiration of the figs. However, figs given a preventive treatment did not have an increase in respiration. This could be explained by the synergistic effect between the compounds present in the essential oil and chitosan, which are widely recognized for their antimicrobial properties (Escamilla-García et al., 2017). With the exception of figs inoculated and with curative treatment, the data 
obtained were similar to those reported by Baldoni et al. (2016), who determined a respiration rate ranging from 69.4 to $86.9 \mathrm{~mL}$ of $\mathrm{CO}_{2} \mathrm{~kg}^{-1} \mathrm{~h}^{-1}$ in figs stored at $5{ }^{\circ} \mathrm{C}$ for 16 days and coated with chitosan, beeswax and essential oils of cinnamon and lemon.

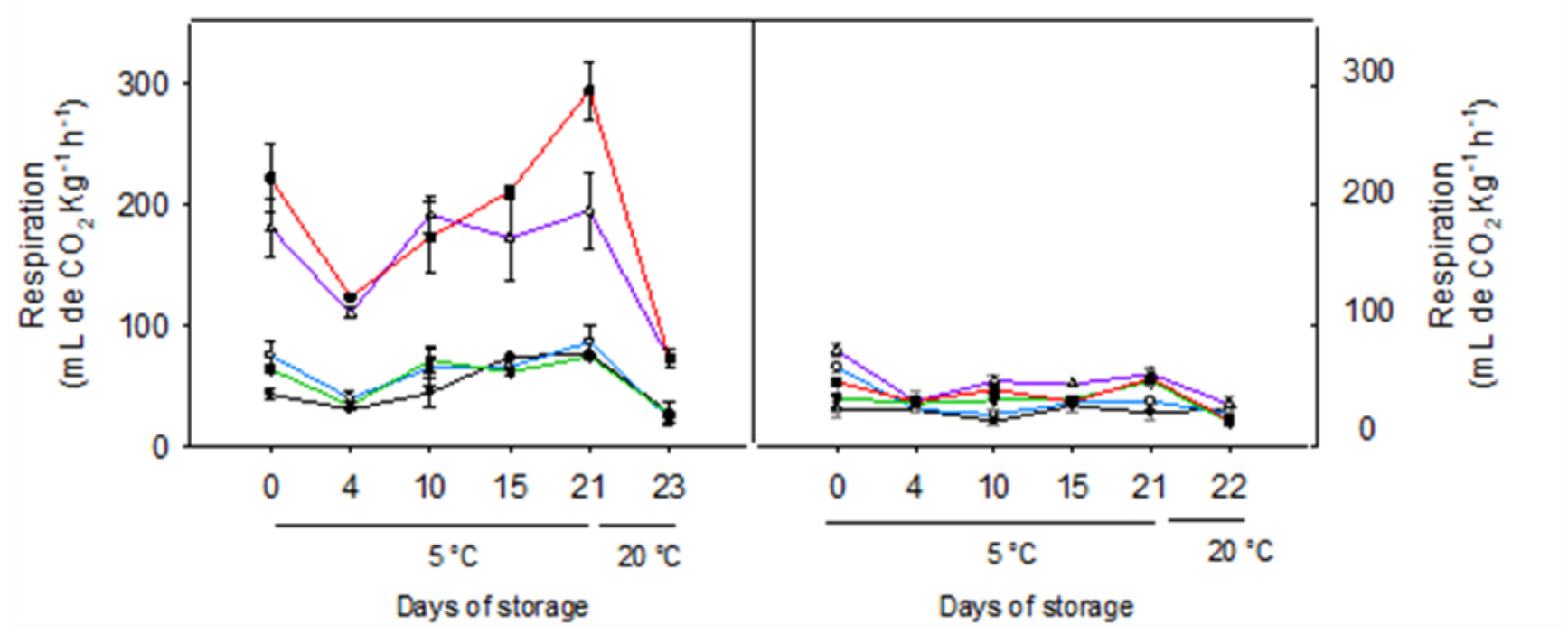

Figure 3 Respiration rate (mL de CO2 kg-1 h-1) of unripe (A) and ripe (B) figs stored at $5{ }^{\circ} \mathrm{C}$ for $21 \mathrm{~d}$ and after at 20 ${ }^{\circ} \mathrm{C}$. T1: control group $(-\boldsymbol{-})$; T2: coated $(-\boldsymbol{-})$, T3: preventive $(\boldsymbol{\nabla})$, T4: curative $(\Delta-)$, and T5: figs inoculated with A. alternata $(\rightarrow)$ ). Vertical bars represent the standard deviation $(\mathrm{p} \leq 0.05)$.

\subsection{Effect of BC on antioxidants compounds}

Overall, anthocyanin's content of ripe and unripe figs gradually increased over time. Ripe fruit had more anthocyanins than unripe ones. The increase is probably because, in full ripening, figs undergo a color change, which is associated with the increase of anthocyanins (Solomon et al., 2006). The ripe figs of the control group, figs with curative treatment as well as the ripe figs inoculated with the fungus, presented the highest anthocyanins content $\left(150 \mathrm{mg} \mathrm{kg}^{-1}\right)$ after day 15 (Figures 4A and 4B). This is possible since anthocyanins can act as antimicrobial agents and the fruits when exposed to the pathogen, produces more compounds as a defense mechanism (Kong et al., 2003). On the other hand, despite the high content of anthocyanins found in Roselle calyces, the concentration used in the BC did not modify the content of the anthocyanins in the fruits. Çalişkan \& Polat (2011) evaluated the anthocyanin content of several fig cultivars, reporting an average value of $128.4 \mathrm{mg} \mathrm{kg}^{-1}$, data that coincide with those obtained in this research.

Regarding the antioxidant capacity, no significant differences ( $\mathrm{p} \leq 0.05)$ were observed in terms of the maturity stage or the treatments applied for 21 days at $5{ }^{\circ} \mathrm{C}$. However, at the end of the storage period at $20^{\circ} \mathrm{C}$, the fruits (unripe and ripe) inoculated with $A$. alternata had the highest antioxidant capacity (Figures 4C and 4D), as well as the figs treated with coatings or fungi. On this, Ventura-Aguilar et al., (2013) reported that plants respond to different types of stress including pathogen infection, producing a reactive oxygen species that stimulate the synthesis of molecules that act as antioxidants. Consequently, an increase in antioxidant capacity was found on the commodities. Solomon et al. (2006) reported an antioxidant capacity ranging from 0.20 to $19.8 \mu \mathrm{mol} \mathrm{g}^{-1}$ using the ABTS radical for evaluation for six varieties of figs. 


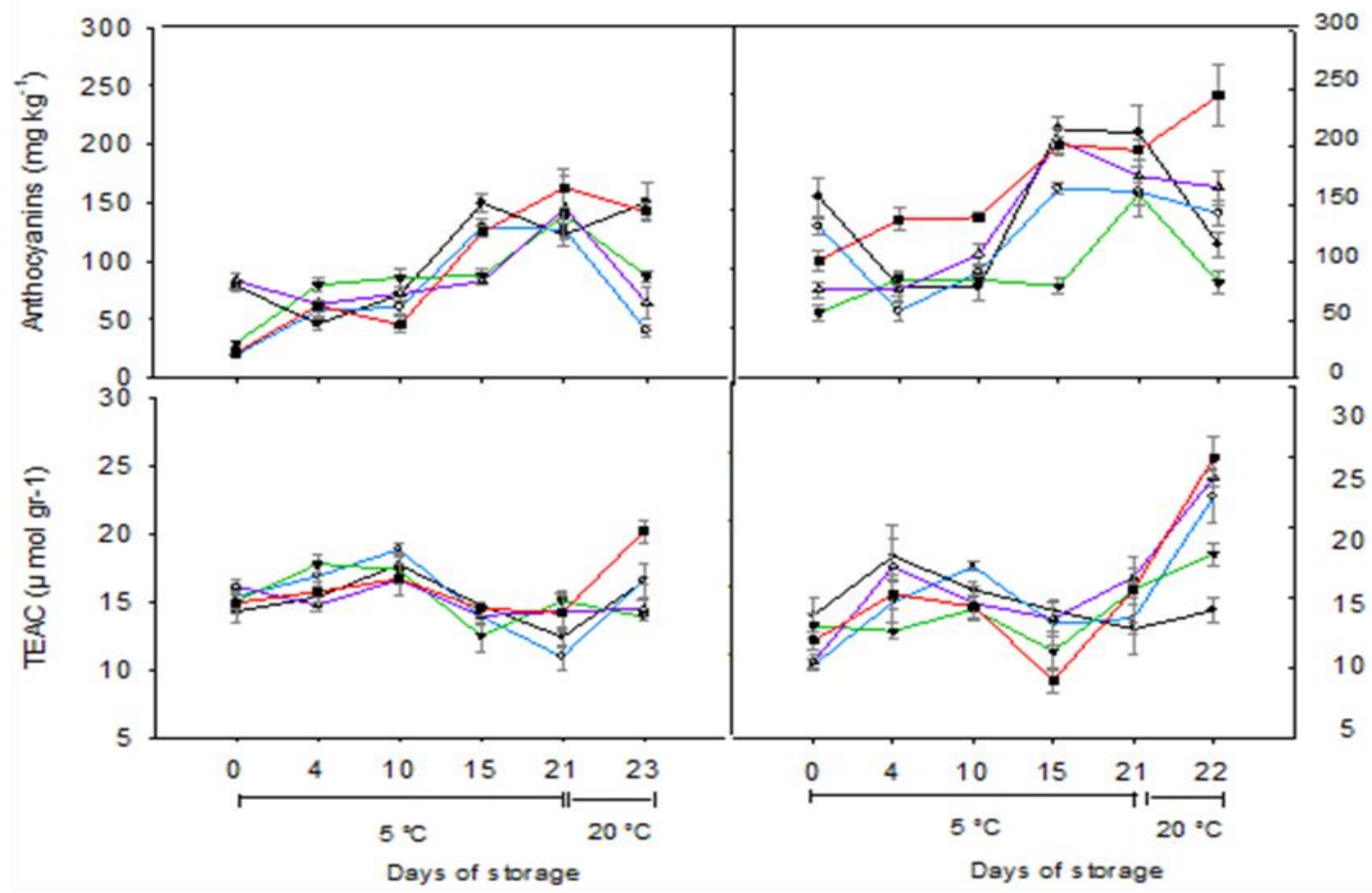

Figure 4 Antioxidant compounds of unripe (A and C) and ripe (B and D) figs stored at $5{ }^{\circ} \mathrm{C}$ for $21 \mathrm{~d}$ and after at $20{ }^{\circ} \mathrm{C}$. T1: control group ( - ); T2: coated $(\stackrel{-}{-})$, T3: preventive $(\vec{\nabla})$, T4: curative $(\Delta-)$, and T5: figs inoculated with A. alternata $(-)$ ). Vertical bars represent the standard deviation $(p \leq 0.05)$.

\subsection{Incidence and severity of rotting on figs}

Unripe figs did not show symptoms of rotting during storage at $5{ }^{\circ} \mathrm{C}$. This was because low temperatures delay fungi growth since their optimum condition oscillates between $25^{\circ} \mathrm{C}$ and $28{ }^{\circ} \mathrm{C}$ (Pontón et al., 2002). In addition, the integrity cell wall of unripe figs acts as a barrier that prevents the establishment of fungi. On the other hand, in ripe fruits, fungal growth was observed on the last day of storage at $5{ }^{\circ} \mathrm{C}$. By increasing the storage temperature to $20^{\circ} \mathrm{C}$, unripe fruits were affected by the fungus, but the incidence was significantly higher $(\mathrm{p}<0.001)$ in ripe fruits, regardless of treatments. Furthermore, the treatments applied negatively affected unripe fruits, since the control group had the lowest incidence of the disease until day 23 (Figures 5A and 5B). On the other way, the severity of the disease caused by A. alternata increased over time in all the figs evaluated (ripe and unripe) and it was not significantly different in terms of the treatments applied ( $\mathrm{p} \leq 0.05)$. However, this was higher in ripe fruits during storage at 5 and $20^{\circ} \mathrm{C}$. At the end of the evaluation (day 24), in ripe fruits, the severity was twofold higher than those unripe ones (Figures 5C and 5D). As outlined previously, unripe figs have a non-optimal composition for the development of pathogens (low TSS content), which explains the incidence and low severity of diseases on them. Unlike the results obtained in this study, Cantín et al. (2011) reported that $A$. alternata did not grow on figs treated with sulfur dioxide and stored at $0^{\circ} \mathrm{C}$ for 7 days. However, when the temperature was increased to $20^{\circ} \mathrm{C}$ for 4 days, it showed an incidence $15 \%$ lower than the control group. 


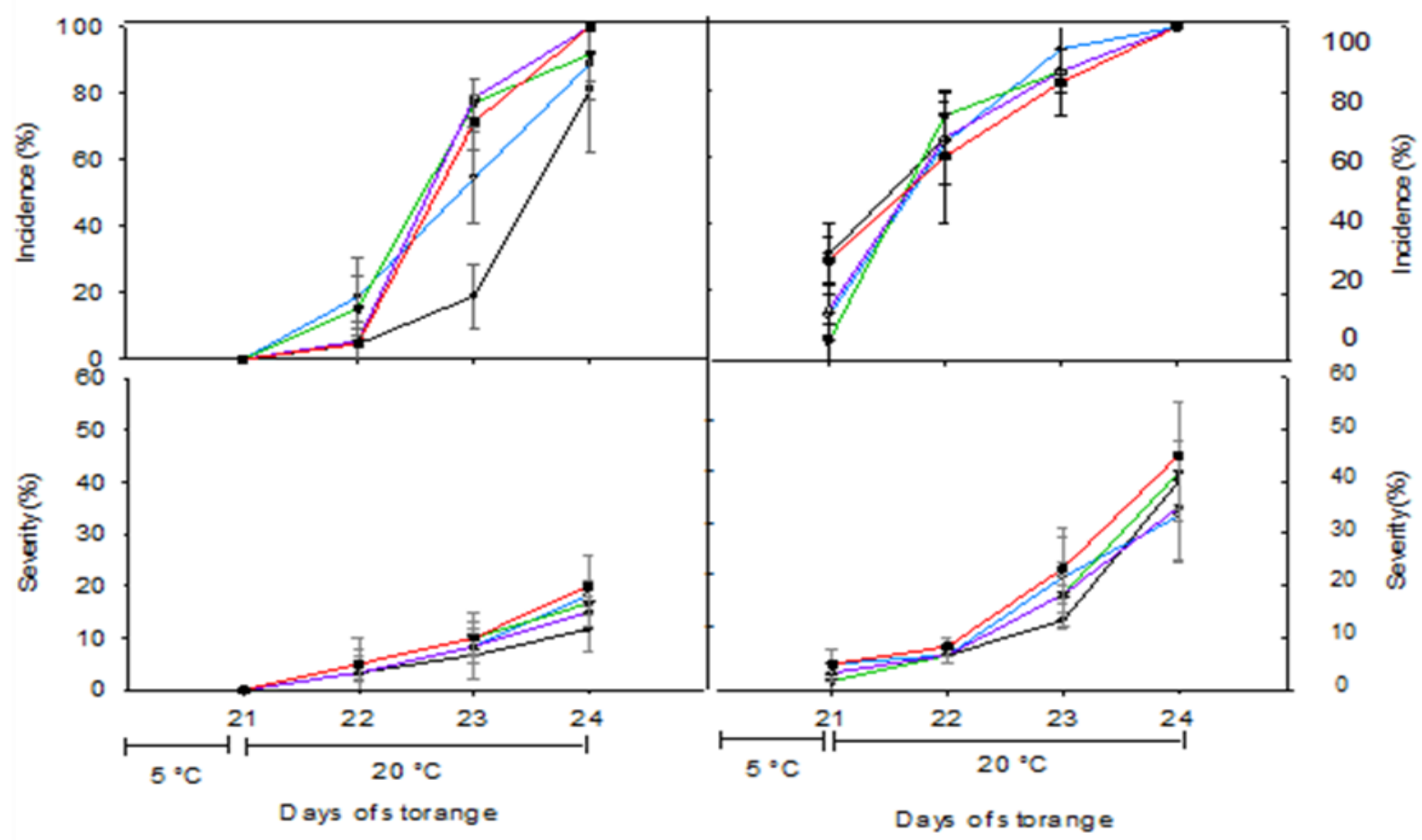

Figure 5 Incidence and severity of unripe (A and C) and ripe (B and D) figs stored at $5{ }^{\circ} \mathrm{C}$ for $21 \mathrm{~d}$ and after at $20^{\circ} \mathrm{C}$.

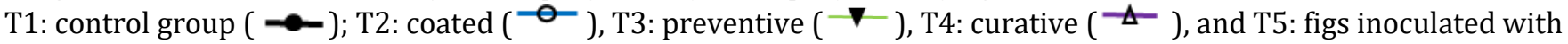
A. alternata $(\rightarrow-)$. Vertical bars represent the standard deviation $(p \leq 0.05)$.

\section{Conclusion}

In the case of unripe figs, using $\mathrm{BC}$ and preventive treatment their quality and antioxidant compounds were preserved. Furthermore, these figs did not show growth $A$. alternata during 21 days at $5^{\circ}$. In the case of ripe figs, using $\mathrm{BC}$, as well as the preventive and curative treatment only the color change of fruits was delayed.

\section{Compliance with ethical standards}

\section{Acknowledgments}

The authors thank the Center of Nanosciences and Micro and Nanotechnologies of Instituto Politécnico Nacional for her support to analyze the structure of the film by SEM.

\section{Disclosure of conflict of interest}

The authors declare no potential conflict of interest.

\section{References}

[1] Aguilera-Ortiz M, Alanis-Guzmán MG, García-Díaz CL and Hernández-Brenes CM. (2009). Caracterización y estabilidad de antocianinas de higo, variedad Mission. Universidad y Ciencia, 25(2), 151-158.

[2] Allegra A, Sortino G, Inglese P, Settanni L, Todaro A and Gallotta A. ( 2017) . The effectiveness of Opuntia ficusindica mucilage edible coating on post-harvest maintenance of 'Dottato' fig (Ficus carica L.) fruit. Food Packaging and Shelf Life, 12, 135-141.

[3] Alturki S. (2013). Utilization of modified atmosphere packaging to extend the shelf-life of fresh figs. Biotechnology, 12(2), 81-86.

[4] AOAC. (2005). Official Methods of Analysis of AOAC International. In Association of Official Analysis Chemists International. 
[5] Baldoni D, Ventura-Aguilar RI, Hernández López M, Corona-Rangel ML, Barrera-Necha L, Correa-Pacheco Z and Bautista-Baños S. (2016). Calidad Postcosecha De Higos 'Black Mission' Tratados Con Cubiertas Naturales. Revista Iberoamericana de Tecnología Postcosecha, 17(2), 267-275.

[6] Bautista-Baños S, Ventura-Aguilar RI, Correa-Pacheco Z and Corona-Rangel ML. (2017). Chitosan: a versatile antimicrobial polysaccharide for fruit and vegetables in postharvest-a review Quitosano: un polisacárido antimicrobiano versátil para frutas y hortalizas en poscosecha-una revisión: a versatile antimicrobial polysaccharide for fruit. Revista Chapingo Serie Horticultura, 23(2), 103-121.

[7] Çalişkan 0 and Polat AA. (2011). Phytochemical and antioxidant properties of selected fig (Ficus carica L.) accessions from the eastern Mediterranean region of Turkey. Scientia Horticulturae, 128(4), 473-478.

[8] Cantín CM, Palou L, Bremer V, Michailides TJ and Crisosto CH. (2011). Evaluation of the use of sulfur dioxide to reduce postharvest losses on dark and green figs. Postharvest Biology and Technology, 59(2), 150-158.

[9] Crisosto CH, Bremer V, Ferguson L and Crisosto GM. (2010). Evaluating quality attributes of four fresh fig (Ficus carica $L$.) cultivars harvested at two maturity stages. HortScience, 45(4), 707-710.

[10] Doster MA and Michailides TJ. (2007). Fungal decay of first-crop and main-crop figs. Plant Disease, 91(12), 16571662.

[11] Escamilla-García M, Calderón-Domínguez G, Chanona-Pérez JJ, Mendoza-Madrigal AG. Di Pierro P, GarcíaAlmendárez BE, Amaro-Reyes A and Regalado-González C. (2017). Physical, structural, barrier, and antifungal characterization of chitosan-zein edible films with added essential oils. International Journal of Molecular Sciences, 18(2370), 1-14.

[12] FAOSTAT. (2018). Production quantity of fig.

[13] Flaishman MA, Rodov V and Stover E. (2007). The Fig: Botany, Horticulture, and Breeding. In Jules Janick (Ed.), Horticultural Reviews, 113-196.

[14] Haci D and Özcan M. (2018). Effects of packaging and ozone treatments on quality preservation in purple figs. Acta Scientiarum Polonorum, Hortorum Cultus, 17(2), 83-92.

[15] Hosseini MH, Razavi SH and Mousavi MA. (2009). Antimicrobial, physical and mechanical properties of chitosanbased films incorporated with thyme, clove, and cinnamon essential oils. Journal of Food Processing and Preservation, 33, 727-743.

[16] Kader AA. (2003). A summary of CA requirements and recommendations for fruits other than apples and pears. Acta Horticulturae, (600), 737-740.

[17] Kong JM, Chia LS, Goh NK, Chia TF and Brouillard R. (2003). Analysis and biological activities of anthocyanins. Phytochemistry, 64(5), 923-933.

[18] Kou X, He Y, Li Y, Chen X, Feng Y and Xue Z. (2019). Effect of abscisic acid (ABA) and chitosan/nano-silica/sodium alginate composite film on the color development and quality of postharvest Chinese winter jujube (Zizyphus jujuba Mill. cv. Dongzao). Food Chemistry, 270, 385-394.

[19] Kuskoski EM, Asuero AG, Troncoso AM, Mancini-Filho J and Fett R. (2005). Aplicación de diversos métodos químicos para determinar actividad antioxidante en pulpa de frutos. Ciência e Tecnologia de Alimentos, 25(4), 726-732.

[20] Lakshmi SJ, Roopa B, Sharanagouda H, Ramachandra CT, Nadagouda S and Nidoni U. (2018). Effect of biosynthesized zinc oxide nanoparticles coating on quality parameters of fig ( Ficus carica $L$.) fruit. Journal of Pharmacognosy and Phytochemistry, 7(3), 10-14.

[21] Latinović N, Radišek S and Latinović J. (2014). First report of Alternaria alternata causing fruit rot on fig (Ficus carica) in Montenegro. Plant Disease, 98(3), 424.

[22] Marpudi SL, Ramachandran P and Srividya N. (2013). Aloe vera gel coating for post-harvest quality maintenance of fresh fig fruits. Research Journal of Pharmaceutical, Biological and Chemical Sciences, 4(1), 878-887.

[23] Martínez K, Ortiz M, Albis A, Gutiérrez CG, Valencia ME and Grande CD. (2018). The effect of edible chitosan coatings incorporated with Thymus capitatus essential oil on the shelf-life of strawberry (Fragaria $\mathrm{x}$ ananassa) during cold storage. Biomolecules, 8(155).

[24] Pontón J, Moragues MD, Gené J, Guarro J and Quindós G. (2002). Hongos y actinomicetos alergénicos. España: Revista Iberoamericana de Micología. 
[25] Re R, Pellegrini N, Proteggente A, Pannala A, Yang M and Rice-Evans C. (1999). Antioxidant activity applying an improved ABTS radical cation decolorization assay. Free Radical Biology and Medicine, 26(9-10), 1231-1237.

[26] Reyes-Avalos MC, Femenia A, Minjares-Fuentes R, Contreras-Esquivel JC, Aguilar-González CN, Esparza-Rivera JR and Meza-Velázquez JA. (2016). Improvement of the quality and the shelf life of figs (Ficus carica) using an alginate-chitosan edible film. Food and Bioprocess Technology, 9(12), 2114-2124.

[27] Self Nutrition Data. (2018). Figs, raw nutrition facts \&amp; calories.

[28] Shan B, Cai Y, Brooks JD and Corke H. (2007). Antibacterial properties and major bioactive components of cinnamon stick (Cinnamomum burmannii): Activity against foodborne pathogenic bacteria. Journal of Agricultural and Food Chemistry, 55(14), 5484-5490.

[29] Solomon A, Golubowicz S, Yablowicz Z, Grossman S, Bergman M, Gottlieb HE, Altman A, Kerem Z and Flaishman MA. (2006). Antioxidant activities and anthocyanin content of fresh fruits of common fig (Ficus carica L.). Journal of Agricultural and Food Chemistry, 54(20), 7717-7723.

[30] Vazquez-Briones MC and Guerrero-Beltrán JA. (2013). Recubrimientos de frutas con biopelículas. Temas Selectos de IIgeniería de Alimentos, 7(2), 5-14.

[31] Veberic R, Colaric M and Stampar F. (2008). Phenolic acids and flavonoids of fig fruit (Ficus carica L.) in the northern Mediterranean region. Food Chemistry, 106(1), 153-157.

[32] Ventura-Aguilar RI, Bautista-Baños S, Flores-García G and Zavaleta-Avejar L. (2018). Impact of chitosan based edible coatings functionalized with natural compounds on Colletotrichum fragariae development and the quality of strawberries. Food Chemistry, 262, 142-149.

[33] Ventura-Aguilar RI, Rivera-Cabrera F, Méndez-Iturbide D, Pelayo-Zaldívar C and Bosquez-Molina E. (2013). Enzymatic and non-enzymatic antioxidant systems of minimally processed cactus stems (Opuntia ficus-indica Mill.) packaged under modified atmospheres. International Journal of Food Science and Technology, 48(12), 2603-2612.

[34] Villalobos MC, Serradilla MJ, Martín A, Ruiz-Moyano S, Pereira C and Córdoba MG. (2016). Synergism of defatted soybean meal extract and modified atmosphere packaging to preserve the quality of figs (Ficus carica L.). Postharvest Biology and Technology, 111, 264-273.

\section{How to cite this article}

Contreras SS, Ventura AR, Bautista BS and Barrera NL. (2020). Biodegradable chitosan coating for improving quality and controlling Alternaria alternata growth in figs. World Journal of Advanced Research and Reviews, 7(2), 115-125. 